\title{
Justifiable defense against environmental crime? a theoretical thinking triggered by china's collective environmental events
}

\begin{abstract}
The justifiable defense issues of Environmental Crime directly relate to the basic human rights of the populace and stable development of society. Previous justifiable defense research can only explain justifiable defense issues in the context of some Environmental Crime. However, the major theoretical issues, such as how to cognize the urgency of cumulative crimes, whether a unit subject can conduct justifiable defense or not, and whether a group can conduct justifiable defense jointly or not, need to be studied further. The cooperation-competition risks that Environmental Crime possess characterize the competition between latent and accumulative legal interest infringement mode and the conventional legal interest infringement mode, as well as the impact of the flexible and chemical crime logic of environmental crime concealment on traditional, mechanical and physical crime logic. Meanwhile, these risks also provide us with a new idea to rethink how criminal law theories move ahead in risk society.
\end{abstract}

Keywords: environmental crime, justifiable defense, cooperation-competition risks, risk society, risk criminal law
Volume I Issue 3 - 2017

Ran An
Qufu Normal University, China

Correspondence: Ran An, Qufu Normal University, China, Email i-am-anran@I63.com

Received: October 30, 2017 | Published: November 17, 2017

\section{Introduction}

Justifiable defense is a human self-protection instinct. Thus, it is normally understood as an act with properties of natural law, and possesses a most ancient evolution in terms of the grounds for elimination of illegitimacy. ${ }^{1}$ Justifiable defense is stipulated in Article 20 of China's criminal law:

In the event that stopping illicit infringement acts is undertaken in order to protect national and public interests, one's own or others' personal security, properties or other rights against on-going unlawful infringements, harm to unlawful offender's falls under justifiable defense, bearing no criminal responsibilities. In cases when justifiabledefense obviously exceeds the limits of necessity, causing serious injuries, criminal responsibilities shall be borne, but punishment shall be mitigated or remitted. Although the justifiable defense system in China is explicitly stipulated in the criminal law, but in some cases, it cannot effectively protect the basic human rights of the people because of the limitation of traditional theory and reality.

Among the rapid economic developments in China, the natural environment of China has borne great pressure, and the ecological damage of partial area is very serious. Since the 1990s, the environmental mass incidents in China have entered a peak period, and it became the major problems which triggered the social contradiction, damage of the government's credibility and the impact of social stability development. When Chinese scholars and media pay attention to this phenomenon, they mostly ignore the defensive nature of environmental mass incidents. The reason why most environmental mass incidents took place is that local pollution of the environment has been a serious threat to public health, and even has caused many bad cases. To some extent, the participants of environmental group events seem to be victims of a special environmental crime. However, under the framework of traditional jurisprudence and judicial vision, the victims of environmental crime are unable to defend from the enterprises that manufacture the pollution. In other words, the existing social system does not seem to provide effective relief channels for the victims of environmental crimes. Environmental Crime, side effects which emerge after an economic society develops to a certain degree, are a younger face in the crime family. Environmental Crime have concealment, accumulation, uncertainty and other characteristics, making traditional criminal law theories unable to achieve a seamless connection with them. Therefore, a great many significant areas of criminal law theories are worth our further thought and research.

In recent years, China's research of Environmental Crime has presented an increasingly fiery tendency, but the justifiable defense issues of Environmental Crime have not drawn the due concerns and explorations from academic circles. That is because the factors, such as the fact that Environmental Crime possess concealment, accumulation and other characteristics, the subjects of Environmental Crime are usually unit subjects, and major environmental polluters are sheltered in some places, generally make the criminal results of Environmental Crime unable to meet the urgency requirements of legal interest infringements necessary to justifiable defense. Nevertheless, justifiable defense against Environmental Crime shows little focus on the levels of theoretical research or realistic occurrence, which either signifies that justifiable defense and Environmental Crime do not maintain a shared fate, or we have not paid close enough attention to the events which might have connected the two things together in reality.

As a matter of fact, the collective environmental events which have been happening frequently in China for the past few years are one of the extreme forms of expression of civil self-remedies under new social situations when national protection is absent. ${ }^{2}$ Admittedly, regarding collective environmental events as justifiable defense definitely cannot be justified. However, this paper believes that many 
important theoretical issues are worth our meticulous explorations under the framework of justifiable defense theories. For instance, what the distance is between environmental crime incidents and unjustifiable justifiable defense; when a justifiable defense behavior triggered by Environmental Crime should be initiated; whether a certain number of people can jointly conduct justifiable defense against Environmental Crime; if justifiable defense has a living space when local government protection exists, especially when state-owned enterprises are the pollution subjects of Environmental Crime. All these issues relate to citizens' basic human rights, which has vital practical significance. Furthermore, the research of these issues presents the potential alterations of criminal law theories in risk society to some extent.

\section{Necessary rearrangement of existing justifiable defense theories}

Justifiable-defense actions can match the constitutive requirements of some crimes. But justifiable defense protects relatively superior (or, at least, equivalent) legal interests; therefore, criminal law stipulates explicitly that justifiable defense is permitted. When citizens conduct justifiable defense, certain conditions must be satisfied; otherwise, new unlawful infringements will be created. In general, justifiable defense needs to meet the following conditions: the existence and commission of actual unlawful infringements; the inclination of defenders to protect themselves; the aiming of justifiable defense acts at the unlawful offenders themselves. ${ }^{3}$ In combination with the research theme of this paper, a few important issues of focus require review in the analysis of existing justifiable defense.

First is how to determine the legal interests protected by justifiable defense. 'A necessary justifiable defense action that is implemented in order to protect themselves or others against on-going illegal infringements', ${ }^{4}$ the classical definition of justifiable defense succinctly states the protective legal interest issues of justifiable defense. Literally, 'others' surely includes national and social legal interests; however, on a theoretical level, it is controversial whether the protective legal interests of justifiable defense can be expanded to pubic legal interests or not. Positive doctrines believe that pubic legal interests can be limitedly admitted on an extremely urgent occasion when salvation from state public organs cannot be anticipated..$^{5}$ Negative doctrines think that pubic legal interests cannot be self-defended; otherwise, every citizen can dignifiedly consider themselves to be a rescue policeman, making the national monopolistic jurisdiction lose effect. ${ }^{6}$ Also, compromise doctrines consider that justifiable defense can be taken if not only pubic but also personal legal interests are infringed, but the behaviors of purely infringing pubic legal interests or whole law orders cannot be selfdefended. ${ }^{7}$ Although there are controversies in terms of criminal law theories, according to the stipulation stated in Article 20 of China's criminal law, it should not be unreasonable to bring national, social and other public legal interests into the protection circle of justifiable defense.

Second is whether justifiable defense against a juridical person or social organization can be conducted or not. For this issue, academic circles mainly have three opinions: negative doctrines consider that a juridical person or social organization cannot be an object to be self-defended. The reason is that justifiable defense primarily aims at personal infringements, which determines that harmful means are mainly injurious behaviors. Consequently, conducting justifiable defense against a juridical person or social organization performing illegal infringements is impossible, and only a natural person implementing unlawful infringements in the name of a juridical person or social organization can be self-defended against. ${ }^{8}$ Basic negative doctrines believe that illegal infringements performed by a juridical person cannot be self-defended against in general. Since the behaviors of units harming people are commonly irrepressible, and not the illicit infringements of criminal law theories, justifiable defense cannot be conducted in general. However, a juridical person's unlawful infringements typically need to be executed by a natural person in an organization; thus, justifiable defense against that natural person, which should be identified as justifiable defense against the juridical person, can attain the purpose of safeguarding legal interests. ${ }^{9}$ Positive doctrines think that China's criminal law does not forbid justifiable defense against a juridical person or social organization. Therefore, as long as the criminal offenses of a juridical person or social organization possess the qualitative and quantitative characteristics of unlawful infringements, the right to justifiable defense against them can be exercised. ${ }^{10}$

Third is how to judge whether illicit infringements are ongoing or not. On this issue, previous criminal law theories mainly adopted exclusionary methods to ascertain on-going infringements. Justifiable defense must aim at on-going illegal infringements, which denotes that justifiable defense is generally invalid when defenders direct against imaginary, past, future or self-defeating infringements, or defenders have other legal remedies. ${ }^{11}$ As for the start time of unlawful infringements in criminal law theories, there are various interpretations, such as: entry into the infringement scene, commencement, direct confrontation, overall doctrines (in general, the commencement doctrine is considered a standard judgment; on special occasions, the direct confrontation doctrine is considered a standard judgment) and other doctrines. ${ }^{12}$

Fourth is how to identify unjustifiable justifiable defense. Article 20 (2) of China's criminal law stipulates: 'In case justifiable defense obviously exceeds the limits of necessity, causing serious injuries, criminal responsibilities shall be borne, but punishment shall be mitigated or remitted.' This is the general provision about unjustifiable justifiable defense. Theoretically, how to identify 'the limits of necessity' contains different doctrines, such as fundamental adaptability, necessity and propriety doctrines. In other words, 'Every act necessary to restrain unlawful infringements and protect legal interests is within the limits of necessity...Conclusions shall be drawn through comprehensively analyzing cases'. ${ }^{13}$

\section{Perceptions of environmental crime issues feebly subsumed by existing justifiable defense doctrines}

The traits of Environmental Crime themselves, such as diffusivity and accumulation of legal interest infringement results, determine that existing justifiable defense research cannot satisfy the demands of justifiable defense interpreted in Environmental Crime, which also represents the incapability and helplessness of conventional criminal law theories which started from modern industrial society logic under present social conditions.

Firstly, diffusivity and other traits of some environmental crime results render the populace unable to conduct justifiable defense, risking people's fundamental human rights. For instance, when 
Environmental Crime manifest as water and air contamination, the mobility and diffusivity of their legal interest infringement effects are extremely strong, which might threaten numerous unspecified people? Moreover, the remedies of public power also hardly eliminate risks in a timely manner, and the general populace is even unable to conduct justifiable defense given the nature of self-help remedies. In other words, when some Environmental Crime happen, the populace cannot conduct justifiable defense, but must accept infringement consequences unavoidably even if the remedies of public power are in a vacant state, which undoubtedly makes people's lives occur in restless and anxious circumstances. In accordance with the establishment conditions of previous justifiable defense, the above situations can completely meet the conditions of initiating justifiable defense: infringements which directly menace human lives or health and possess urgency occur; the remedies of public power are absent temporarily; when the aim is to protect their own life safety and health as well as other transpersonal legal interests; when possibilities of self-defending against the subjects of crimes (no matter a natural person or unit subject) exist.

However, we cannot take effective self-defensive measures for protecting ourselves, which shows that existing justifiable defense research has not taken such possible situations into consideration, and also lets us see that the logic and thoughts of traditional criminal law research feebly face some current crime problems to some extent. We should soberly realize that the above and similar situations are not environmental torts within the scope of general civil remedies, but environmental crime behaviors that criminal law needs to govern. As Locke said: Where the law that is enacted to protect me cannot intervene with then strong forces in order to safeguard my life, and the life cannot be compensated once it is lost, I can self-defend and enjoy the right of war... since violators do not allow me to have time to resort to our common judges or juridical sentences to salvage an irretrievable injury. ${ }^{14}$

For general environmental torts, we perhaps can placidly accept post-remedying solutions; but, when facing Environmental Crime that directly threaten human life safety, we, at least, should not lack selfremedy defensibility on a theoretical level.

Secondly, since the legal interest infringement results of some Environmental Crime possess a relatively long incubation period or accumulative results, previous justifiable defense research did not pay much attention to such issues. ${ }^{15}$ Admittedly, on the surface, the incubative and accumulative peculiarities of Environmental Crime indeed lack the urgent requirements of constituting justifiable defense. But this article believes that the legal interest infringements of Environmental Crime are unduly uncertain, which is likely to severely menace the lives and health of non-localized crowds; thus, it is necessary to re-examine the urgent requirements of constituting justifiable defense. The core elements of the urgencies required by justifiable defense generally refer to the situations which are ongoing and encroach on or threaten a natural person's life or health, and Environmental Crime can precisely meet the two core demands of urgencies. It is undisputed that Environmental Crime can infringe on or imperil a natural person's life or health, but the point is how to identify the 'threshold' of Environmental Crime encroaching on human beings. Environmental Crime can often cause critical illnesses or other personal injuries to humans, plus Environmental Crime may threaten numerous people in more than one area. Therefore, when environmental crime acts have started affecting people's health, it does not seem unadvisable to identify them as having possessed the urgencies required by justifiable defense. Certainly, it still needs a longer period to put the theoretical discussions into practice.

Only when the development of scientific and technological means is able to meet the precision required by this kind of identification can this be achieved. On the other hand, the signs of urgencies still have room for further discussions in the context of Environmental Crime. For example, where several wicked environmental crime incidents have happened or relatives and friends have been seriously violated in a local area, it is totally normal that the general populace from the same community or living zone suffers from a fearful and anxious psychological state. Then, how can they ascertain whether they themselves have been affected more or less, whether they are already in an urgently hazardous condition and can they implement justifiable defense in order to protect their own or others' legitimate rights and interests? This paper thinks that, no matter what the answers to these questions are, we should be imperturbably aware that the above situations are 'present progressive' to a certain extent, and probably becoming even more violent with the development and changes of all kinds of conditions. This is not only a provocation of existing justifiable defense research by Environmental Crime, but also a challenge of a new social situation vis-à-vis traditional criminal law theories. The seriousness of Environmental Crime warrants proposing their re-examination under criminal law; along with this, we should consider a competition of incubative and accumulative legal interest infringement modes represented by Environmental Crime along with straightforward and conventional legal interest infringement modes. As Environmental Crime conflict with traditional crime types, so, too, do the impacts of the flexible and chemical crime logic of environmental crime concealment affect traditional, mechanical and physical crime logic.

Thirdly, if all aspects of requirements of establishing justifiable defense are satisfied, how does the general populace conduct justifiable defense when some Environmental Crime are protected by local authorities? In recent years, collective environmental events have been emerging on an ever-accelerating basis, which elicit a sense of distress and repugnance, and many media outlets also constantly magnify collective environmental event participants' losses and pathos. There is no denying that collective environmental events are gradually becoming one of the major obstacles influencing social stability and development. However, the core focus of such incidents lies precisely in that collective environmental events tend to possess certain legitimate foundations when they are happening, which provides opportunities for us to analyze the connection between such affairs and justifiable defense:

According to the recent and socially influential collective environmental events listed in the above table, we can conclude that they possess the following characteristics: 1 . The reason for collective environmental events has gradually extended from already-built polluting units to planned units and those under construction. In other words, the public has gradually extended justifiable defense against infringements from actual to expectable infringements; 2 . Competing with polluting units at the beginning has developed into pointing fingers at local powers charged with protecting public rights; 3 . Most events have certain brewing periods, but they gradually shorten; 4 . To a great extent, most incidents will break out after legal means are exhausted; 5. Events refer to popular lives and health with an extremely strong characteristic of participation. 
In conclusion, we clearly find that collective environmental events can be completely interpreted with the establishment formula of justifiable defense theory, but it always seems incorrect to put collective environmental events and justifiable defense together for comparison. After all, collective environmental events often appear as collective acts of unrest, gravely damaging legal orders and impeding social stability and development. This paper believes that it is never advisable to glorify such acts as justifiable defense, but we should not neglect the elements which possess certain justifiable defense characteristics and fall just short of collective environmental events. The following questions are worth our consideration: Firstly, can collective justifiable defense be allowed? Ever since the third scientific and technological revolution, the development of social productivity has made people unable to attend to all matters, and development of nuclear, biological, information technologies indeed flourishes with each passing day. All kinds of scientific and technological developments enable enterprises to organize production activities on a larger scale, but the quantity of production risks increase at the same time. Once pernicious accidents happen, numerous people in multiple localities will be infringed upon. Manufacturing enterprises which are closely associated with the environment are especially likely to encounter such incidents. The major difference between collective environmental events and other types of collective events is that environmental risks directly menace people's most basic right to exist while other types of collective events more easily remedied by redistribution of benefits, especially economic benefits. In a multitude of collective environmental events, polluting enterprises can bring prominent advantages to local governments and residents, but the local populace would rather give up employment opportunities and other value which might bring risks to their own right to survival Consequently, collective environmental events, which feature a level of participation incomparable with other types of events, tend to be a hundred responses to a single call. In fact, any legislation has its practical social foundations. Potential damage offenses in the criminal law field, special justifiable defense and other concepts all possess highly directional sophisticated weapons, and are all enacted special provisions aimed at criminal elements which significantly encroach on legal interests. Then, after current situations change, we ought to consider whether justifiable defense will appear in front of the common people as collective justifiable defense in the future, and how we dissect and analyze it in the research field of criminal law.

Secondly, can justifiable defense methods be expanded? Existing justifiable defense research has not made explicit restrictions for justifiable defense modes, but we can feel that traditional justifiable defense tends to be a face-to-face act of individual to individual or the few to the few; in other words, this is a synchronic act with a very small spatial distance; while future justifiable defense will probably be an act touched off by diachronic factors involving many people. Consequently, traditional justifiable defense behaviors taking physical contacts as core elements may wither away gradually while this new form of non-interpersonal-antagonism justifiable defense will be moving towards the proscenium. Taking justifiable defense against Environmental Crime for instance, people's knowledge about delitescent and accumulative danger is likely to strengthen constantly, and the knowledge of urgencies in the context of justifiable defense may be amended as well. On occasion, if the production activities of polluting enterprises are paused by cutting off water and electricity supplies or taking other non-interpersonal-antagonism measures, and unnecessary legal interest infringements are indeed not triggered meanwhile, can a similar way become one of the justifiable defense modes against Environmental Crime? Otherwise, if the populace is not endowed with a new self-salvation channel, people's fundamental human rights will be squeezed continually, making collective events unavoidable. To reiterate, under the current social situation, we should, on a theoretical level, undertake a certain degree of preconception and analysis of justifiable defense prospects that may occur in the future, rather than always waiting on developing social situations to force our thinking and institutional construction. Otherwise, against the backdrop of current rapid social development and vigorous momentum, we will probably be bewildered with an adverse outcome, and its wicked social influences cannot yet be imagined.

Thirdly, how to self-defend against or deal with infringement acts protected by local authorities? It can be seen from the above table that the friction between current collective environmental incidents and local governments has become more frequent because the socially significant and influential collective environmental events happening in China tend to be a struggle along three sides; namely, the populace, enterprises and local governments. Especially for the past two or three years, collective environmental events against planned projects or those under construction happening throughout the country have directly pointed to the local governments who brought these projects into development while demotic emotions pointed to polluting enterprises in most previous events. ${ }^{17}$ There is no denying that former justifiable defense research might not consider the situation which is happening at present. If general public power executives encroach on the populace illegally, ${ }^{18}$ the infringed can naturally conduct justifiable defense and even special justifiable defense.

However, when encountering infringements from public power with a defective system and institution, the populace may supposedly turn to collective environmental events out of a sense of helplessness. In recent years, people's living space has been narrowed to the extreme in some regions. Objectively, most parts of China still urgently need economic growth to change their backward outlook, and development of many public utilities also requires the support of local economic bases in order to provide the populace with better public welfare. But, in such situations, so-called 'rational ignorance' events have been exposed continually. Some local governments 'naively' believe some unscientific reports on environmental impact assessment, and hurriedly approve the projects which may cause serious pollution to be undertaken. Thus, although a great many institutional taxpayers bring about severe environmental pollution, they are also 'indulged rationally', eventually resulting in people's basic human rights to be 'ignored rationally'. This article believes that, when the similar situations exist, an outburst of collective environmental events is not at all surprising, and even lets people experience some solemn color of justice. As has been said above, it is inadvisable to beautify collective environmental incidents with violence as justifiable defense. However, whether we can sense an implication of unjustifiable justifiable defense against these events, or make a few connections between collective environmental events and the legal principles behind unjustifiable justifiable defense, which can not only appropriately mitigate participants' obligations in collective environmental events, but also enhance the authority and credibility of governments, we can lay a solid public opinion foundation for the lasting and stable development of society. Overall, along with significantly enhanced social and folk strengths nowadays, we should never rely on political authorities to one-dimensionally carry out economic growth and maintain social stability, but give more respect 
to people's fundamental human rights and corresponding demands. Specific to the justifiable defense issues of Environmental Crime, we should at least realize that the statement bases of previous theories have changed significantly. Exploring boldly on a theoretical level may render unto the public more protective ideas and methods; thus, we can never stick to former theoretical frameworks and doctrinal viewpoints.

\section{Cooperation-competition risk: the forward} axle of criminal law theories in the context of risk society

In recent years, the term and concept 'risk society' appears frequently, and its visibility is very high, whether in mass media or theoretical research, and the criminal law research field proves to be no exception. Within the framework of risk society, the placement of criminal law theories has undoubtedly been one of the trending topics studied by criminal law in recent years, and some scholars have even put forward the concept of 'risk criminal law' and unfolded relatively systematic argumentation. ${ }^{19}$ Risk society theories 'seem to tally with some explanatory and constructive demands of China's criminal law circle, resulting in its sudden popularity. Lots of criminal theories, opinions and propositions seem to have found a legitimate basis in terms of sociology'. ${ }^{20}$ As a matter of fact, for transmutation of criminal law theories under risk society and risk criminal law theories, their promise and perils overlap drastically, but the distinct propositions from the two camps may carry the burden of oversimplifying problems. The commentators from both groups seem to have ignored that China is currently in the process of transforming into a risk society; thus, even if we are considered to have entered the risk society, traditional and modern risks also have cooperationcompetition parts. However, how best to understand and explain this cooperation-competition risk in criminal law theories is the pivotal affair of our current criminal law theory research.

\section{Mixed judgments: the life orbit of risk criminal law theories}

The point-making logic of risk criminal law theories are roughly as follows: first, explain that risk and traditional societies have tremendous differences, and the danger level of risks in risk society is far more than traditional risks; allege that risk society has arrived, and traditional criminal law is unable to do what it wants very much to do when coping with modern risks, which is evidence that risk criminal law theories have been born at the right moment. ${ }^{21}$ As for where risk criminal law theories are specifically embodied, scholars have given many different standpoints. For example, Professor Chen Xiaoming expounded upon the canonical form of risk criminal law from five aspects: legal interest abstraction, deed fictionalization, criminal penalty forwardness, culpability functionalization and precaution activation, ${ }^{22}$ Associate professor Lao Dongyan summarized the seven aspects of differences between risk and traditional criminal laws: antedisplacement of conviction standards, development of behavior categories, expansion of responsibility scopes and diversification of responsibility forms, increase and decrease of key constitutive elements of crimes, innovation of causality criteria, expansion of fiction and presumption, as well as setting of legal circumstances for sentencing, ${ }^{23}$ Professor Zhang Mingkai identified the three aspects of propositions of risk criminal law theories: the range of punishment is enlarged (such as increasing involuntary dangerous crimes), the grounds of illegality are not the valuelessness of consequences, but the valuelessness of behaviors, and strict liability ought to be adopted instead of adhering to responsibility doctrines. ${ }^{24}$ In summary, risk criminal law theories place particular emphasis on orders rather than freedoms, and on the valuelessness of behaviors rather than the valuelessness of consequences in basic positions; on the claim of concrete issues, risk criminal law roundly amplifies crime circles by expanding legislative and judicatory levels, constituting a relatively major breakthrough for traditional culpability criminal law.

There are approximately three kinds of theoretical logic behind criticisms of risk criminal law theories. Firstly, at the beginning when risk criminal law theories were published, scholars mostly maintained criticism of risk criminal law on the basis of the basic standpoints and spirits of traditional criminal law. For instance, professor Chen Xingliang pointed out: 'Risk criminal law' can admittedly play a certain role in the process of relieving risks, but 'risk criminal law' itself also has certain criminal law risk...If criminal law overly expands and even breaks through criminal punishment legalism for alleviating the risks of risk society, such criminal law is definitely inadvisable. ${ }^{25}$

In another instance, Professor Yu Zhigang ${ }^{26}$ pointed out: Even if risks are closer to us, it does not mean that 'risk criminal law' should be closer to us. Justice, civilization, modesty, conservativeness and other spiritual values implied in criminal law represent hundreds of years of the exploratory crystallization of human society, which should not be easily abandoned in modern society. At every step, expansion of crime circles ought to withstand more legitimate interrogations and censure. ${ }^{26}$

Some scholars have criticized risk criminal law theories by reflecting risk society theories. As professor Zhang Mingkai pointed out: "'Risk society' is not necessarily an actual status of society, but the outcomes of culture or governance". ${ }^{27}$ After some discussion, some commentators deem that the viewpoints of supporting and criticizing risk criminal law theories may all distort the real meaning of risk categories in the context of risk society. Criminal law of classical society cannot defuse the risks of risk society, and the risks of risk society belong to systematic crises. The solution first depends on institutional reflection upon science and politics. ${ }^{28}$ Professor Chen Xingliang also pointed out: 'The risks of risk society are the technical risks of post-industrial society. These types of risks possess unpredictability and uncontrollability, making them completely unable to enter the adjustment range of criminal law' ${ }^{29}$

In conclusion, we can find that the viewpoints of supporting and criticizing risk criminal law theories are indeed a clear distinction between black and white; especially, the newest criticism of risk criminal law theories is indeed not superficial. Nevertheless, this article believes that criminal law powerlessly modifying the technical risks of post-industrial society is convictive, but whether criminal law is able to rework aforementioned cooperation-competition risks (cooperation-competition of traditional and modern risks) has debatable room.

\section{Sudden enlightenment: Initial consideration of cooperation-competition risks}

Environmental crises are the typical manifestation of risk society. Professor Beck, the founder of risk society theories clearly pointed out: 'I say that risks first refer to the toxins and pollutants in radioactive substances, air, water and food that completely escape from human perceptive ability', ${ }^{30}$ While making a speech at the Russian Duma, 
professor Beck also mentioned risks on three levels, which could be confirmed as global risks, the first of which was ecological crises. ${ }^{31}$ On a macroscopic level, ecological crises are undoubtedly one of the modern risks in the context of risk society, but on a micro level, ecological crises are composed of every deed and event of contaminating the environment. Nevertheless, acts which pollute the environment are usually caused by the relatively primitive capacities of traditional industrial society or the unlawful acts which established criminal law can govern instead of by the advanced technologies of post-industrial society.

Combined with the discussion topic of this article, we realize that the means and modes of Environmental Crime are usually orthodox, foreseeable and controllable, but the legal interest infringement results of Environmental Crime are always unpredictable and uncontrollable; moreover, the accumulative effects of Environmental Crime are generally unforeseeable and uncontainable, which means that Environmental Crime, to a great extent, have become the cooperation-competition point of both traditional and neoteric crimes, as well as the embodiments of the cooperation-competition point of traditional and modern risks. Consequently, justifiable defense in the context of Environmental Crime suggests that issues can only partially be explained by traditional criminal law theories and only through further innovative thought can most of the issues be solved. Because they possess the traits of both conventional and novel crimes, Environmental Crime are very likely to cause stronger and wider legal interest infringements to human society. Nevertheless, our current research neglects the existence of cooperation-competition risks, such as Environmental Crime, transforming risk criminal law theories from an object of praise into the target of criticism by certain groups. However, in the presence of vivacious and ever-changing social realities, denying risk criminal law or conventional criminal law in risk society needs a certain degree of breakthrough, which makes people feel insecure and even faint-hearted, fearing that, once criminal law theories inappropriately handle new social situations, greater and unimaginable adverse consequences will be brought about.

This paper is not intended to clamor for encouraging risk criminal law theories, but, by excavating cooperation-competition risks, gives consideration to the progressive postures which criminal law theories in risk society might possess. For example, some commentators pointed out that the risks in traditional society are legalized as modern 'potential side effects', which conceals the economic rationality of measuring costs and benefits, requiring a weighing of 'opportunitieswealth' and 'danger-damage'. Only if the latter wins can the risks in traditional society be forbidden by criminal law. Nevertheless, globalization, uncertainty and systemization of risk society all place the hazards of risk society and the nature of traditional criminal law at odds; therefore, traditional criminal law powerlessly coordinates the risks of risk society. On a legislative level, an expansion of risk criminal law theories is invalid, and legal interest protection is unable to surpass civil, administrative and other precondition laws no matter how it is put forward. Additionally, expansion of risk criminal law theories in criminal justice is also invalid (Table 1):

Table I Disorderly collective environmental events triggered by environmental pollution in recent years. ${ }^{16}$

\begin{tabular}{|c|c|c|c|c|c|}
\hline $\begin{array}{l}\text { Major } \\
\text { Events }\end{array}$ & Event Time & $\begin{array}{l}\text { Polluting } \\
\text { Enterprises }\end{array}$ & $\begin{array}{l}\text { Period of } \\
\text { Dispute }\end{array}$ & $\begin{array}{l}\text { Number of } \\
\text { Participants }\end{array}$ & Protest Mode \\
\hline $\begin{array}{l}\text { Fuchuan, } \\
\text { Guangxi } \\
\text { Event }\end{array}$ & $\begin{array}{l}\text { From } 4 \text { to } 5 \\
\text { September } 2003\end{array}$ & $\begin{array}{l}\text { Fuchuan County } \\
\text { Arsenic Factory }\end{array}$ & $\begin{array}{l}\text { From } 1997 \\
\text { to } 2003\end{array}$ & Hundreds & $\begin{array}{l}\text { Appealing to the higher authorities for help many } \\
\text { times, and conflicting with the manufacturer and } \\
\text { the police. }\end{array}$ \\
\hline $\begin{array}{l}\text { Dongyang, } \\
\text { Zhejiang } \\
\text { Event }\end{array}$ & $\begin{array}{l}\text { From } 20 \text { March to } \\
10 \text { April } 2005\end{array}$ & $\begin{array}{l}\text { Several Chemical } \\
\text { Plants in the Zhuxi } \\
\text { Industrial Park }\end{array}$ & $\begin{array}{l}\text { From } 2001 \\
\text { to } 2005\end{array}$ & $\begin{array}{l}20,000 \text { to } \\
30,000\end{array}$ & $\begin{array}{l}\text { Appealing to the higher authorities for help } \\
\text { many times, and conflicting with law enforcement } \\
\text { officials and the police. }\end{array}$ \\
\hline $\begin{array}{l}\text { Major } \\
\text { Events }\end{array}$ & Event Time & $\begin{array}{l}\text { Polluting } \\
\text { Enterprises }\end{array}$ & $\begin{array}{l}\text { Period of } \\
\text { Dispute }\end{array}$ & $\begin{array}{l}\text { Number of } \\
\text { Participants }\end{array}$ & Protest Mode \\
\hline $\begin{array}{l}\text { Xinchang, } \\
\text { Zhejiang } \\
\text { Event }\end{array}$ & $\begin{array}{l}\text { From } 4 \text { to } 17 \text { July } \\
2005\end{array}$ & $\begin{array}{l}\text { Xinchangjing } \\
\text { Pharmaceutical } \\
\text { Factory }\end{array}$ & $\begin{array}{l}\text { From } 1990 \\
\text { to } 2005\end{array}$ & Nearly 10,000 & $\begin{array}{l}\text { Appealing to the higher authorities for help many } \\
\text { times, and conflicting with the manufacturer and } \\
\text { the police. }\end{array}$ \\
\hline $\begin{array}{l}\text { Cenxi, } \\
\text { Guangxi } \\
\text { Event }\end{array}$ & $\begin{array}{l}\text { From } 9 \text { to } 10 \\
\text { January } 2007\end{array}$ & $\begin{array}{l}\text { Zhongtaifu Paper } \\
\text { Company }\end{array}$ & $\begin{array}{l}\text { From } 2006 \\
\text { to } 2007\end{array}$ & Nearly 100 & $\begin{array}{l}\text { Appealing to the higher authorities for help many } \\
\text { times, and conflicting with the manufacturer and } \\
\text { the police. }\end{array}$ \\
\hline $\begin{array}{l}\text { Liuyang, } \\
\text { Hunan } \\
\text { Event }\end{array}$ & $\begin{array}{l}\text { From } 28 \text { May to } 30 \\
\text { July } 2009\end{array}$ & $\begin{array}{l}\text { Changsha Xianghe } \\
\text { Chemical Plant }\end{array}$ & $\begin{array}{l}\text { From } 2004 \\
\text { to } 2009\end{array}$ & Thousands & $\begin{array}{l}\text { Appealing to the higher authorities for help many } \\
\text { times, and conflicting with the manufacturer and } \\
\text { the police. }\end{array}$ \\
\hline $\begin{array}{l}\text { Fengxiang, } \\
\text { Shanxi } \\
\text { Event }\end{array}$ & $\begin{array}{l}\text { From II to } 16 \\
\text { August } 2009\end{array}$ & $\begin{array}{l}\text { Shanxi Dongling } \\
\text { Group }\end{array}$ & $\begin{array}{l}\text { From } 2006 \\
\text { to } 2009\end{array}$ & Hundreds & $\begin{array}{l}\text { Appealing to the higher authorities for help many } \\
\text { times, and conflicting with the manufacturer and } \\
\text { the police. }\end{array}$ \\
\hline $\begin{array}{l}\text { Quangang, } \\
\text { Fujian } \\
\text { Event }\end{array}$ & $\begin{array}{l}\text { From } 19 \text { to } 31 \\
\text { August } 2009\end{array}$ & $\begin{array}{l}\text { District Sewage } \\
\text { Treatment Plant }\end{array}$ & $\begin{array}{l}\text { August } \\
2009\end{array}$ & Hundreds & Conflicting with the manufacturer and the police. \\
\hline $\begin{array}{l}\text { Jingxi, } \\
\text { Guangxi } \\
\text { Event }\end{array}$ & $\begin{array}{l}\text { From II to I } 3 \text { July } \\
2010\end{array}$ & $\begin{array}{l}\text { Jingxi Xinfa } \\
\text { Aluminium } \\
\text { Manufacturer }\end{array}$ & $\begin{array}{l}\text { From } 2007 \\
\text { to } 2010\end{array}$ & Thousands & $\begin{array}{l}\text { Appealing to the higher authorities for help many } \\
\text { times, and conflicting with the manufacturer and } \\
\text { the police. }\end{array}$ \\
\hline
\end{tabular}


Table Continued....

\begin{tabular}{|c|c|c|c|c|c|}
\hline $\begin{array}{l}\text { Major } \\
\text { Events }\end{array}$ & Event Time & $\begin{array}{l}\text { Polluting } \\
\text { Enterprises }\end{array}$ & $\begin{array}{l}\text { Period of } \\
\text { Dispute }\end{array}$ & $\begin{array}{l}\text { Number of } \\
\text { Participants }\end{array}$ & Protest Mode \\
\hline $\begin{array}{l}\text { Haining, } \\
\text { Zhejiang } \\
\text { Event }\end{array}$ & $\begin{array}{l}\text { From } 26 \text { August to } \\
16 \text { September } 2011\end{array}$ & $\begin{array}{l}\text { Haining Jingke } \\
\text { Energy Company }\end{array}$ & $\begin{array}{l}\text { From } 2006 \\
\text { to } 2011\end{array}$ & Hundreds & $\begin{array}{l}\text { Appealing to the higher authorities for help many } \\
\text { times, and conflicting with the manufacturer and } \\
\text { the police. }\end{array}$ \\
\hline $\begin{array}{l}\text { Deqing, } \\
\text { Zhejinag } \\
\text { Event }\end{array}$ & $\begin{array}{l}\text { From the beginning } \\
\text { of March to April } \\
2011\end{array}$ & $\begin{array}{l}\text { Haijiu Battery } \\
\text { Company }\end{array}$ & $\begin{array}{l}\text { From } 2003 \\
\text { to } 2011\end{array}$ & Hundreds & $\begin{array}{l}\text { Appealing to the higher authorities for help, and } \\
\text { conflicting with the manufacturer and the police. }\end{array}$ \\
\hline $\begin{array}{l}\text { Xiamen } \\
\text { PX Event }\end{array}$ & June of 2007 & $\begin{array}{l}\text { Xianglu Dragon } \\
\text { Group }\end{array}$ & June 2007 & Thousands & $\begin{array}{l}\text { Collectively expressing opinions without fierce } \\
\text { conflicts. }\end{array}$ \\
\hline $\begin{array}{l}\text { Shanghai } \\
\text { Magnetic } \\
\text { Suspension } \\
\text { Event }\end{array}$ & $\begin{array}{l}\text { From } 6 \text { January to } \\
\text { the middle of the } \\
\text { month } 2008\end{array}$ & $\begin{array}{l}\text { Shanghai-Hangzhou } \\
\text { Magnetic Suspension } \\
\text { (Shanghai Section) }\end{array}$ & $\begin{array}{l}\text { January } \\
2008\end{array}$ & Thousands & $\begin{array}{l}\text { Collectively expressing opinions without fierce } \\
\text { conflicts. }\end{array}$ \\
\hline $\begin{array}{l}\text { Zhenhai, } \\
\text { Ningbo } \\
\text { Event }\end{array}$ & $\begin{array}{l}\text { From } 22 \text { to } 26 \\
\text { October } 2012\end{array}$ & Zhenhai PX Project & $\begin{array}{l}\text { From } 2010 \\
\text { to } 2012\end{array}$ & Thousands & $\begin{array}{l}\text { Conflicting with law enforcement officials and } \\
\text { the police. }\end{array}$ \\
\hline $\begin{array}{l}\text { Shifang, } \\
\text { Sichuan } \\
\text { Event }\end{array}$ & $\begin{array}{l}\text { From } 3 \text { to } 4 \text { July } \\
2012\end{array}$ & $\begin{array}{l}\text { Hongda Mo-Cu } \\
\text { Project }\end{array}$ & July 2012 & $\begin{array}{l}\text { Tens of } \\
\text { thousands }\end{array}$ & $\begin{array}{l}\text { Conflicting with law enforcement officials and } \\
\text { the police. }\end{array}$ \\
\hline $\begin{array}{l}\text { Qidong, } \\
\text { Zhejiang } \\
\text { Event }\end{array}$ & 28 July 2012 & $\begin{array}{l}\text { Oji Paper Group Sea } \\
\text { Drainage Project }\end{array}$ & $\begin{array}{l}\text { From June } \\
\text { to July } \\
2012\end{array}$ & $\begin{array}{l}\text { Tens of } \\
\text { thousands }\end{array}$ & $\begin{array}{l}\text { Conflicting with law enforcement officials and } \\
\text { the police. }\end{array}$ \\
\hline
\end{tabular}

Expansion of criminal justice wants nothing but to improve some deterrence of penalty, which has not got rid of the risk control logic of classical industrial society yet. It is beneficial for controlling the risks of traditional society, such as traffic and mine accidents, but such post-deterrence is invalid for those destructive global risks. ${ }^{32}$

This paper reflects that the above analyses are rational, but stand a chance of handling issues carelessly without considering the possible impacts on criminal law brought by the cooperation-competition risks of Environmental Crime. Environmental crises are global risks, which may bring tremendous disorder to various people in non-localized regions. But environmental crises are characterized by inexorable accumulation while other risks (such as nuclear explosions) are more sudden. At present, most modes of making environmental crises increasingly worse are still subject to classical industrial societies, and most acts which cause Environmental Crime have not exceeded the categories governed by traditional criminal law, as yet. Then, for manipulating the unknown legal infringement results of Environmental Crime, the behavior control categories that traditional criminal law can play a role in are given certain pre-protection on a criminal legislation level; and on a criminal judicature level, reinforcing regulatory force against Environmental Crime and improving deterrence of environmental criminal law are not unsystematic and instead may become an effective choice for benefiting current social realities.

To reiterate, if the existing cooperation-competition risks in Environmental Crime are the key nodes of understanding and cutting through traditional and risk criminal laws, the management and control of these kinds of risks are able to provide a safer guarantee for a present-day China which is in a period of rapid development and exhibits high-incidence risks.

\section{Conclusion}

The justifiable defense against Environmental Crime highlights the deficiencies of former justifiable defense research, as well as the regrettable realities of social confusion forcing theoretical thinking. On the premise that previous justifiable defense theory statement bases have substantial changes, we must rethink the meaning of legal interest infringement urgencies, the issues of whether a unit subject can be self-defended or not and how to self-defend, as well as the legitimacy issues of collective justifiable defense. All these issues directly relate to the basic human rights of the populace and the stable development of society; hence, the matter is of great significance. The cooperation-competition risks owned by Environmental Crime are the key to understanding the above issues, as well as the means to reconsider how criminal law theories in risk society may be altered. Since China's society is at a stage of drastic development and transformation, and there may exist many other types of crime with cooperation-competition risks, we, theoretically, cannot carelessly classify them into traditional or modern groupings, but need to treat them separately in a deliberate way. Only then can we anticipate that criminal law research will indeed become the future theories of humanistic pragmatism, reassuring the at-risk populace.

\section{Acknowledgments}

None.

\section{Conflict of interest}

The author declares no conflict of interest.

\section{References}

1. Otsuka H. Generality of Criminal Law (Pandect). China: China Renmin University Press; 2009. 371 p.

2. In recent years, China's collective environmental events have entered a high-incidence season. Collective environmental events have become a significant issue creating social contradictions, damaging government credibility and influencing social stability and development. In: Wang Yanchun, editor. How to Break through Plight of Collective Environmental Events, from Chinese Cadres Tribune. $3^{\text {rd }}$ issue. 2013. 
3. Zhang M. Criminal Jurisprudence. Australia: Law Press; 2011. p. 191201.

4. Yescheck HH, Weigend T. Lehrbuch des deutschen Strafrechts. China: China Legal Publishing House; 2009. 403 p.

5. Ootani M. Pandect of Criminal Law. China: China Renmin University Press; 2009. p. 257-258.

6. Krauss R. German Criminal Jurisprudence-Pandect. Australia: Law Press; 2005. 424 p.

7. Zhang M. Outline of Foreign Criminal Law. Tsinghua University Press, 2007. $162 \mathrm{p}$

8. Chen J. General Theory of Foreign Criminal Law. China: Chinese People's Public Security University Press; 2009. p. 285-286.

9. Ma K. General Theory of Crimes. China: Wuhan University Press; 1995. 709 p.

10. Gao S, Li C. Discussion of Preconditions of Justifiable defense 3 Modern Law Science. 1995.

11. Xiong X, Wu J. Several Considerations on Unlawful Infringements in Justifiable defense 1 Journal of Politics and Law. 1999.

12. Nishida Nori N. General Theory of Japan's Criminal Law. China: China Renmin University Press; 2009. p. 122-124.

13. Locke J. Two Treatises of Government (Part Two). China: The Commercial Press; 1964. 14 p.

14. However, in foreign criminal jurisprudence research, the concept of accumulative crimes is specifically put forward based on the incubative and accumulative traits of Environmental Crime.

15. The partial data in the table are arranged by the author, and some are from Yuming W, Cause Analysis of Collective Environmental Events with Violence-Based on Research of Ten Typical Collective Environmental Events 3 Journal of Zhuhai Administration Institute. 2012.

16. Wang Y. How to Break Through Plight of Collective Environmental Events 3 Chinese Cadres Tribune. 2013.
17. Such as the event that a people's policeman from Guangxi Pingnan County killed a pregnant woman by shooting her after drinking on $28^{\text {th }}$. 2013.

18. Hao Yanbing Y. Risk Criminal Law-An Expansion of Taking Potential Damage Offenses as a Core. China: China University of Political Science and Law Press; 2012.

19. Zhang J. Risk Criminal Law-An Expansion of Taking Precautionary Functions as a Perspective. China: China Legal Publishing House; 2012.

20. Chen X. Criminal Law Responses of Risk Society 6 Chinese Journal of Law. 2009

21. Nan L. Criticism And Reflection of Risk Criminal Law Theories 4 Chinese Journal of Law. 2012

22. Hao. Yanbing above, p. 1-6.

23. Zhang. Jing above, p. 1-2.

24. Chen X. Criminal Law Responses of Risk Society 6 Chinese Journal of Law. 2009.

25. Lao Dongyan D. Criminal Law of Public Policy and Risk Society 3 China Social Sciences. 2007.

26. Zhang M. Reflection on Several Criminal Law Theory Issues in Risk Society 5 Studies in Law and Business. 2011.

27. Chen X. Risk Criminal Law and Criminal Law Risks: Investigation of Double Perspectives 5 Studies in Law and Business. 2011.

28. Yu Z. Risk Criminal Law Is Infeasible 4 Studies in Law and Business 2011.

29. Zhang M. Nan, Lianwei above.

30. Chen X. Legal Dogmatics Criticism of Risk Criminal Law Theories 1 Peking University Law Journal. 2014.

31. Ullrich B. Risk Society. Yilin Press, 2004. 19 p.

32. Ullrich B. World Risk Society after 9.11 Attack 2 Marxism \& Reality. 2004. 